\title{
Stomach content analyses of the threadfin anglerfish Lophiodes spilurus (Lophiiformes: Lophiidae) associated with deepwater shrimp fisheries from the central Pacific of Costa Rica
}

\author{
Mario Espinoza ${ }^{1}$ \& Ingo S. Wehrtmann ${ }^{1,2}$ \\ 1. Centro de Investigación en Ciencias del Mar y Limnología (CIMAR) and Escuela de Biología, Universidad de Costa \\ Rica, San Pedro, San José 2060, Costa Rica; marioespinozamen@yahoo.com \\ 2. Unidad de Investigación Pesquera y Acuicultura (UNIP) of the Centro de Investigación de Ciencias del Mar y \\ Limnología (CIMAR), Universidad de Costa Rica, San Pedro, San José; ingowehrtmann@gmx.de
}

Received 01-X-2007. Corrected 30-VI-2008. Accepted 31-VII-2008.

\begin{abstract}
Our knowledge of deepwater ecosystems along the Pacific of Central America is extremely limited. We analyzed the diet composition of 200 adult specimens of Lophiodes spilurus ranging in size from 7.8 to 17.8 $\mathrm{cm}$ total length (TL). Samples were obtained from deep bottom trawls (depth: 105-238 m) along the central Pacific of Costa Rica. We calculated the percentage of number $(\% \mathrm{~N})$, weight $(\% \mathrm{~W})$, and occurrence $(\% \mathrm{O})$ of each food item encountered in the stomachs; based on this information, the Index of Relative Importance (IR) was calculated. Moreover, we estimated diet overlap for three different size classes $(<10.1,10.1-15.0$ and $>15.1$ $\mathrm{cm} \mathrm{TL})$. The results revealed exclusively two groups of benthic prey items: crustaceans $(30 \%)$ and teleost fish $(70 \%)$ in their diet. The most frequent preys were pandalid shrimps Plesionika trispinus $(\% \mathrm{O}=17)$ and the fathom mora Physiculus rastrelliger $(\% \mathrm{O}=12)$. The greatest diversity and frequency of abundance of food items was observed in intermediate-sized individuals (10.1-15.0 cm TL). Small-sized L. spilurus $(<10.1 \mathrm{~cm}$ TL) fed mainly on teleost fish, while larger $(>15.0 \mathrm{~cm} \mathrm{TL})$ preyed on large-sized stomatopods and teleost fish. There was a clear diet overlap between small and intermediate-sized L. spilurus $(\mathrm{p}<0.05)$. However, differences in diet-overlap were not detected in small and large-sized individuals or intermediate and large-sized specimens ( $\mathrm{p}>0.05$ ). Our results suggest that $L$. spilurus feeds exclusively on crustaceans (Decapoda and Stomatopoda) and benthic teleost fish along the Pacific of Costa Rica. While small and large-sized individuals showed a more pronounced selectivity for certain prey items, the high diversity of benthic prey items observed in intermediatesized specimens suggest a more opportunistic foraging behavior. Rev. Biol. Trop. 56 (4): 1959-1970. Epub 2008 December 12 .
\end{abstract}

Key words: diet composition, deepwater, Lophiodes spilurus, Pacific of Costa Rica, prey items, overlap.

The threadfin anglerfish Lophiodes spilurus (Garman 1899) is a small deepwater benthic anglerfish commonly found on soft sand and mud bottoms in continental waters of the tropical Eastern Pacific (Bussing and López 1993, Allen and Robertson 1994, Nelson 1994). The threadfin anglerfish has a globular appearance with limb-like pectoral fins, flattened head armed with bony spines, a large mouth with sharp teeth, and their first dorsal spine is modified to form a fishingpole apparatus (illicium) with a bait-like esca at its tip (Caruso 1981, 1983, Caruso et al.
2007). However, little is known about the feeding behavior and diet composition of the threadfin anglerfish along the tropical Eastern Pacific. Previous studies have only outlined a general diet composed mainly of fish and crustaceans (Allen and Robertson 1994). Preciado et al. (2006) found that black anglerfish Lophius budegassa from the North Atlantic coast of Spain fed mainly on small benthic fish. However, there is a lack of information regarding systematic investigations of stomach contents in L. spilurus from the Eastern Pacific. 
Stomach content analyses have long been used to assess diet composition and assign trophic level in marine organisms (Hyslop 1980, Cortés 1999). Quantitative analyses of stomach contents provide an important tool to understand and elucidate predator-prey interactions (Cortés 1997, Dávalos and Gonzáles 2003), feeding behavior patterns (Preciado et al. 2006), and ontogenetic shifts (Armstrong et al. 1996). In addition, estimation of prey abundance, frequency of occurrence, weight and relative importance of food items can provide critical ecological information (Joyce et al. 2002, Ibáñez et al. 2004). The threadfin anglerfish L. spilurus is one of the most abundant fish associated with commercial deepwater shrimp fisheries along the coast of Costa Rica. Although our knowledge on ecological aspects of L. spilurus are extremely limited, a detail study of the diet and feeding patterns will help us elucidate more complex ecological interactions and will contribute to our understanding of deepwater systems (Arendt and Olney 2001, Laurenson and Priede 2005).

As part of an intensive onboard sampling program (Wehrtmann and Echeverría-Sáenz, 2007), a large number of stomachs of L. spilurus were collected from specimens taken in the Costa Rican commercial deepwater trawl fishery along the Pacific coast. We provide a quantitative description of the diet of the threadfin anglerfish L. spilurus from the Pacific coast of Costa Rica, and study size-related dietary changes and food overlap. The results of the present investigation will increased our understanding of the diet composition and feeding patterns of the threadfin anglerfish $L$. spilurus in deepwater benthic ecosystems of the Pacific of Costa Rica.

\section{MATERIALS AND METHODS}

Study site: The study area extended approximately from $08^{\circ} 38^{\prime} 02^{\prime \prime}$ to $10^{\circ} 32^{\prime} 10^{\prime \prime}$ $\mathrm{N}$ and $84^{\circ} 05^{\prime} 54^{\prime \prime}$ to $86^{\circ} 10^{\prime} 42^{\prime \prime} \mathrm{W}$, covering the main fishing grounds for the target species, Heterocarpus vicarius. Samples were collected between January and May 2006 in the central Pacific Costa Rica (Fig. 1). The Pacific coast of Costa Rica is 1012 km long, with a continental shelf of approximated 590,000 $\mathrm{km}^{2}$ (Wehrtmann and Cortés, in press). An important portion of the coastal areas along the Pacific of Costa Rica are characterized by estuaries and a large portion of mangroves, which serve as an important site for the reproduction and development of early life stages of many marine species (Molina 1996). Soft bottom and muddy substrates located over a rocky platform dominate the coastal zones, allowing the development of a large variety of organisms (Bussing and López 1993, Dean 2001a, b).

Sampling: Specimens were obtained from daytime (05.00 to $20.00 \mathrm{hrs)}$ commercial shrimp catches in the central Pacific of Costa Rica at depths ranging between 105 and 238 m. A representative subsample of $L$. spilurus (typically 25-30 specimens) was taken, and the following data were recorded and analyzed: standard length (SL; from the tip of the snout to caudal peduncle), total length (TL; from the snout to the extreme of the caudal fin), weight of the fish, and wet weight of the stomach $(\mathrm{g})$. Fishes were eviscerated and each stomach was separated, fixed in formaldehyde $(10 \%)$, and subsequently preserved in $70 \%$ alcohol. An incision was made along the longitudinal axis, and the contents emptied onto a $500-\mu \mathrm{m}$ mesh sieve for rinsing and sorting. Contents were analyzed and identified to the lowest taxonomic level possible. The frequency of occurrence (percent of stomachs which contained a specific prey item, Fo), weight percent (weight of a specific prey item present in all stomachs expressed as percentage of the total weight of the stomachs, $\% \mathrm{~W}$ ), and the average weight per stomach were obtained for the different quantified prey categories (Glenn and Ward 1968, Ikusemiju and Olaniyan 1977, Hyslop 1980); subsequently, these values were compared between different size groups. \% O and $\% \mathrm{~W}$ were examined for three size groups: $<10.1 \mathrm{~cm}, 10.1-15.0 \mathrm{~cm}$, and $>15 \mathrm{~cm}$ TL. Finally, we calculated the index of absolute importance (IA) for all prey items combined 


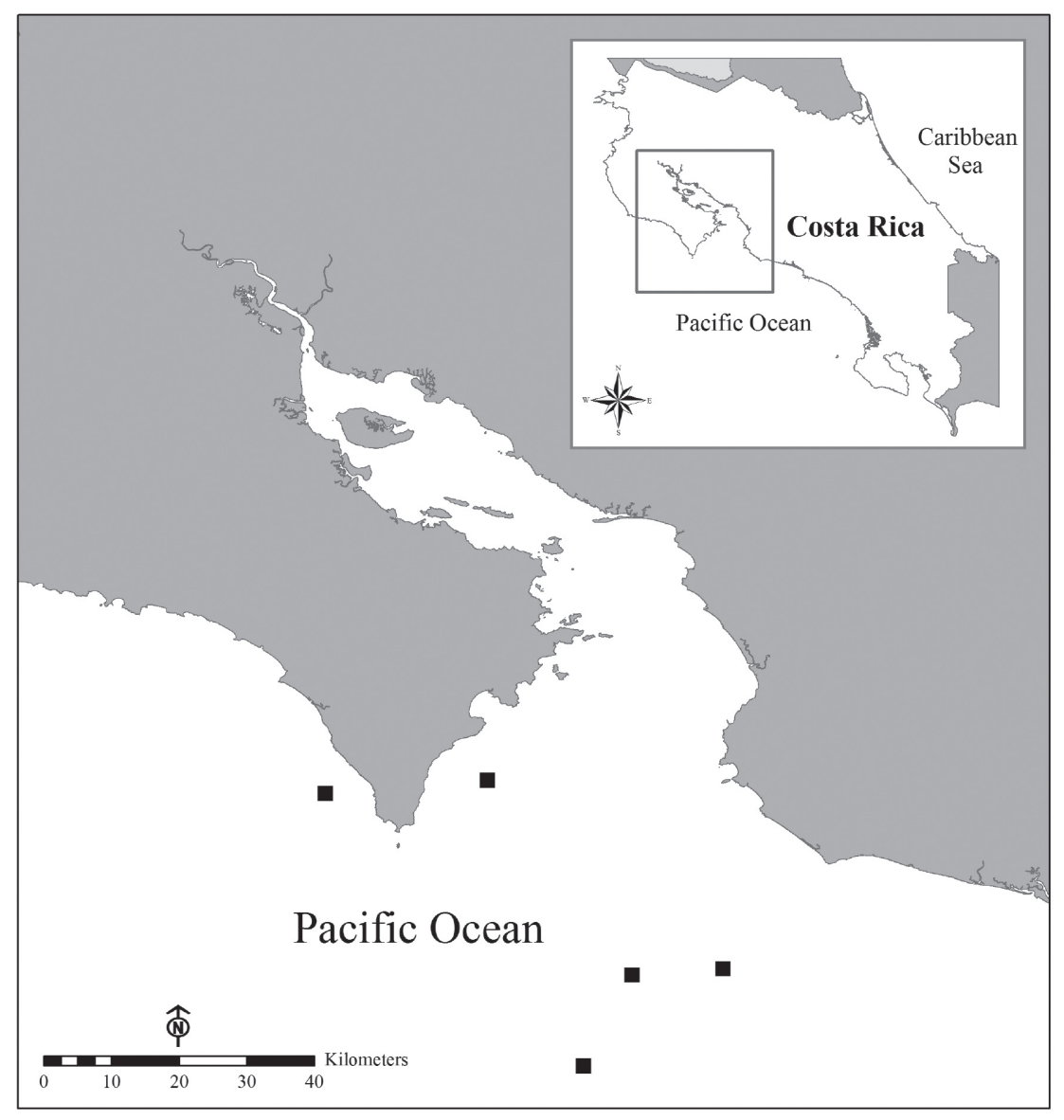

Fig. 1. Study site. The black squares indicate trawling fishing stations in the central Pacific of Costa Rica where threadfin anglerfish (Lophiodes spilurus) specimens were collected.

according to the following formula: IA $=\%$ $\mathrm{O}+\% \mathrm{~N}+\% \mathrm{~W}$, where $\% \mathrm{O}$ as percentage of occurrence of a prey item in the total number of stomachs analyzed; \% $\mathrm{N}$ as the number of individuals of one prey item as percentage of the total prey number, and $\% \mathrm{~W}$ as the percentage of the total stomach weight. Based on the IA, the index of relative importance (IR) was estimated (Hyslop 1980) using the following equation: IR $=\mathrm{IA} / \Sigma \mathrm{IA} \times 100$. The degree of diet overlap in different ontogenetic stages was estimated using the Pianka Index of Niche Overlap. For size group a and b, with resource utilization $\mathrm{p}_{\mathrm{ai}}$ and $\mathrm{p}_{\mathrm{bi}}$, Pianka's (1973) overlap index of size group a on $\mathrm{b}\left(\mathrm{O}_{12}\right)$ was calculated as: $\mathrm{O}_{\mathrm{ab}}=\Sigma\left(\mathrm{p}_{\mathrm{ai}} \mathrm{p}_{\mathrm{bi}}\right) /\left[\left(\mathrm{p}_{\mathrm{bi}}\right)^{2}\left(\mathrm{p}_{\mathrm{ai}}\right)^{2}\right]^{1 / 2}$, where values of $\mathrm{O}_{\mathrm{ab}}>0.60$ indicate a high degree of overlap, $\mathrm{O}_{\mathrm{ab}}<0.29$ a low overlap, and values $0.30<\mathrm{O}_{\mathrm{ab}}<0.59$ indicate the lack of overlap (Krebs 1999). The diversity of prey items were estimated using the Shannon-Wiener index (H') (Pielou 1975, Krebs 1999).

\section{RESULTS}

A total of 200 stomachs from adult threadfin anglerfish (Lophiodes spilurus) collected in the central Pacific of Costa Rica were analyzed (Fig. 1). Individuals ranged from $7.8-17.8 \mathrm{~cm}$ 
total length (average TL: $11.52 \pm 2.17 \mathrm{~cm}$; Fig. 2). Although a large portion of the stomachs analyzed were empty (52\%), individuals with un-empty stomachs $(\mathrm{n}=95)$ contained exclusively crustaceans (30\%) and teleost fish (70\%) as the two major components of their diet (Table 1). Most of the stomachs analyzed contained a single prey item (85\%). Stomachs containing remains of teleost fish (such as vertebrae, spines and soft tissues) and digested shrimps (Table 1) limited the identification of prey items. The largest number of stomachs with at least a single prey item was observed in intermediatesized individuals (10.1-15.0 cm TL) (Fig. 3). Overall, we identified a total of three shrimp species, two stomatopods, one squat lobster, and 14 teleost fish (Table 1). Teleost fish were the most frequent $(\% \mathrm{O}=74.49)$ and important prey item $(\mathrm{IR}=34.18)$. Crustaceans were only present in $25.5 \%$ of the stomachs analyzed (IR $=15.07)$. In addition, stomachs with unidentified teleost fish showed a high frequency of occurrence and relative importance $\left(\mathrm{F}_{\mathrm{o}}=11.5\right.$; $\mathrm{IR}=8.89$ ). Among the prey items identified, $L$. spilurus showed a clear preference for pandalid shrimps Plesionika trispinus and the fathom mora Physiculus rastrelliger (Table 1).

We found significant differences in the proportion of prey items consumed by different size groups $\left(\chi^{2}=8.93, \mathrm{gl}=2, \mathrm{p}=0.011\right)$. Small $\left(<10.1 \mathrm{~cm} \mathrm{TL} ; \chi^{2}=9.94, \mathrm{gl}=1, \mathrm{P}=0.002\right)$ and intermediate-sized individuals (10.1-15.0 $\mathrm{cm}$ TL; $\left.\chi^{2}=15.34, \mathrm{gl}=1, \mathrm{p}<0.001\right)$ consumed a high proportion of teleost fish (> $70 \%$ ). However, the shrimp P. trispinus was the most frequent prey item in intermediate-sized individuals $\left(\mathrm{F}_{\mathrm{o}}=8.5\right)$. Although large-sized L. spilurus ( $>15.0 \mathrm{~cm}$ TL) fed more frequently on larger preys such as stomatopods, we didn't find a significant difference $\left(\chi^{2}=1.29, \mathrm{gl}=1\right.$, $\mathrm{p}>0.05$; Table 2). We also observed a higher diversity of prey items in the diet composition of intermediate-sized individuals (Table 2 and 3 ). According to the Index of Niche Overlap, there was a high degree of food overlap between small- and intermediate-sized individuals $\left(\mathrm{O}_{\mathrm{ab}}\right.$ $=0.68, \mathrm{p}<0.05)$. However, we did not find a significant relationship in the diet overlap of

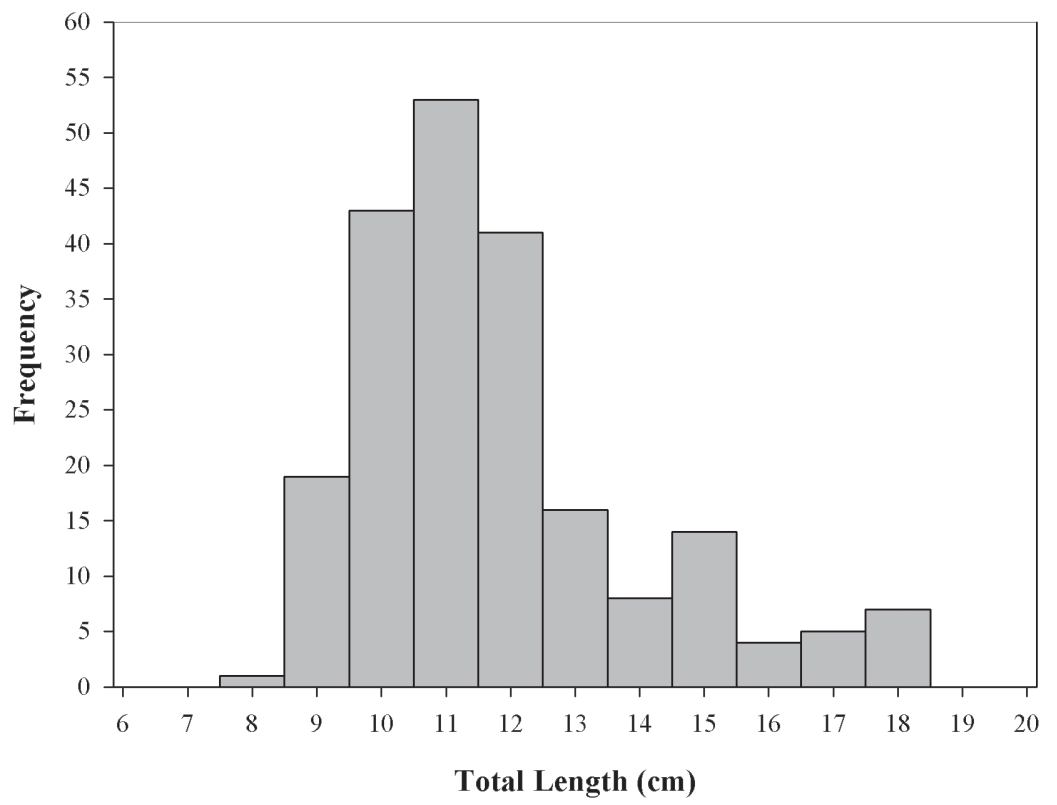

Fig. 2. Length-frequency distribution of the threadfin anglerfish (Lophiodes spilurus) collected in the central Pacific of Costa Rica $(n=200)$. 
TABLE 1

Prey items observed in 200 threadfin angler fish (Lophiodes spilurus) stomachs from the central Pacific coast of Costa Rica, grouped by the two prey categories

\begin{tabular}{|c|c|c|c|c|c|c|c|c|c|}
\hline Prey category & $\mathrm{N}$ & $\% \mathrm{~N}$ & W & $\% \mathrm{~W}$ & $\mathrm{~N}$ & Fo & $\% \mathrm{O}$ & $\mathrm{w}$ & IR \\
\hline Crustacea & 34 & 29.82 & 298.9 & 36.45 & 25 & 12.5 & 25.51 & 3.15 & 15.07 \\
\hline Plesionika trispinus & 20 & 17.54 & 101.7 & 12.40 & 17 & 8.5 & 17.35 & 1.07 & 7.76 \\
\hline Heterocarpus vicarius & 3 & 2.63 & 16.9 & 2.26 & 2 & 1 & 2.04 & 0.18 & 1.11 \\
\hline Solenocera agassizii & 1 & 0.88 & 4.8 & 0.64 & 1 & 0.5 & 1.02 & 0.05 & 0.41 \\
\hline Squilla biformis & 2 & 1.75 & 80.8 & 10.79 & 1 & 0.5 & 1.02 & 0.85 & 2.07 \\
\hline Squilla panamensis & 3 & 2.63 & 87 & 11.61 & 3 & 1.5 & 3.06 & 0.92 & 2.68 \\
\hline Pleuroncodes sp. & 1 & 0.88 & 3.5 & 0.47 & 1 & 0.5 & 1.02 & 0.04 & 0.38 \\
\hline Digested shrimps & 4 & 3.51 & 4.2 & 0.56 & 4 & 2 & 4.08 & 0.04 & 1.33 \\
\hline Teleostei & 80 & 70.18 & 521.1 & 69.56 & 73 & 36.5 & 74.49 & 5.49 & 34.18 \\
\hline Bollmannia stigmatura & 4 & 3.51 & 47 & 6.27 & 4 & 2 & 4.08 & 0.49 & 2.19 \\
\hline Bollmannia sp. & 5 & 4.39 & 44.7 & 5.97 & 5 & 2.5 & 5.10 & 0.47 & 2.45 \\
\hline Brotula clarkae & 1 & 0.88 & 9.2 & 1.23 & 1 & 0.5 & 1.02 & 0.10 & 0.50 \\
\hline Neobythites stelliferoides & 4 & 3.51 & 58.2 & 7.77 & 4 & 2 & 4.08 & 0.61 & 2.41 \\
\hline Lepophidium microlepis & 3 & 2.63 & 30 & 4.00 & 2 & 1 & 2.04 & 0.32 & 1.37 \\
\hline Ophidiidae & 4 & 3.51 & 8.3 & 1.11 & 4 & 2 & 4.08 & 0.09 & 1.41 \\
\hline Physiculus nematopus & 1 & 0.88 & 3.1 & 0.41 & 1 & 0.5 & 1.02 & 0.03 & 0.37 \\
\hline Physiculus rastrelliger & 12 & 10.53 & 101.3 & 13.52 & 12 & 6 & 12.24 & 1.07 & 5.77 \\
\hline Symphurus fasciolaris & 2 & 1.75 & 13 & 1.74 & 2 & 1 & 2.04 & 0.14 & 0.88 \\
\hline Symphurus sp. & 1 & 0.88 & 3.5 & 0.47 & 1 & 0.5 & 1.02 & 0.04 & 0.38 \\
\hline Cynoponticus coniceps & 1 & 0.88 & 9.9 & 1.32 & 1 & 0.5 & 1.02 & 0.10 & 0.51 \\
\hline Hoplunnis pacifica & 4 & 3.51 & 29.3 & 3.91 & 4 & 2 & 4.08 & 0.31 & 1.83 \\
\hline Pontinus sierra & 3 & 2.63 & 25.2 & 3.36 & 3 & 1.5 & 3.06 & 0.27 & 1.44 \\
\hline Prionotus stephanophrys & 1 & 0.88 & 23.5 & 3.14 & 1 & 0.5 & 1.02 & 0.25 & 0.78 \\
\hline Unidentified teleost fish & 24 & 21.05 & 79.2 & 10.57 & 23 & 11.5 & 23.47 & 0.83 & 8.89 \\
\hline Digested teleost fish & 10 & 8.77 & 35.7 & 4.77 & 10 & 5 & 10.20 & 0.38 & 3.83 \\
\hline TOTAL & 114 & 100 & 820 & 100 & 95 & 49 & 100 & 8.63 & 100 \\
\hline
\end{tabular}

$\mathrm{N}$ : number of organisms; \% O: percentage of occurrence; W: total weight (g); \% W: percentage weight in g; n: number of stomachs with prey item; Fo: frequency of occurrence; \% O: percentage of occurrence; and w: weight per stomach sample in $\mathrm{g}$. 


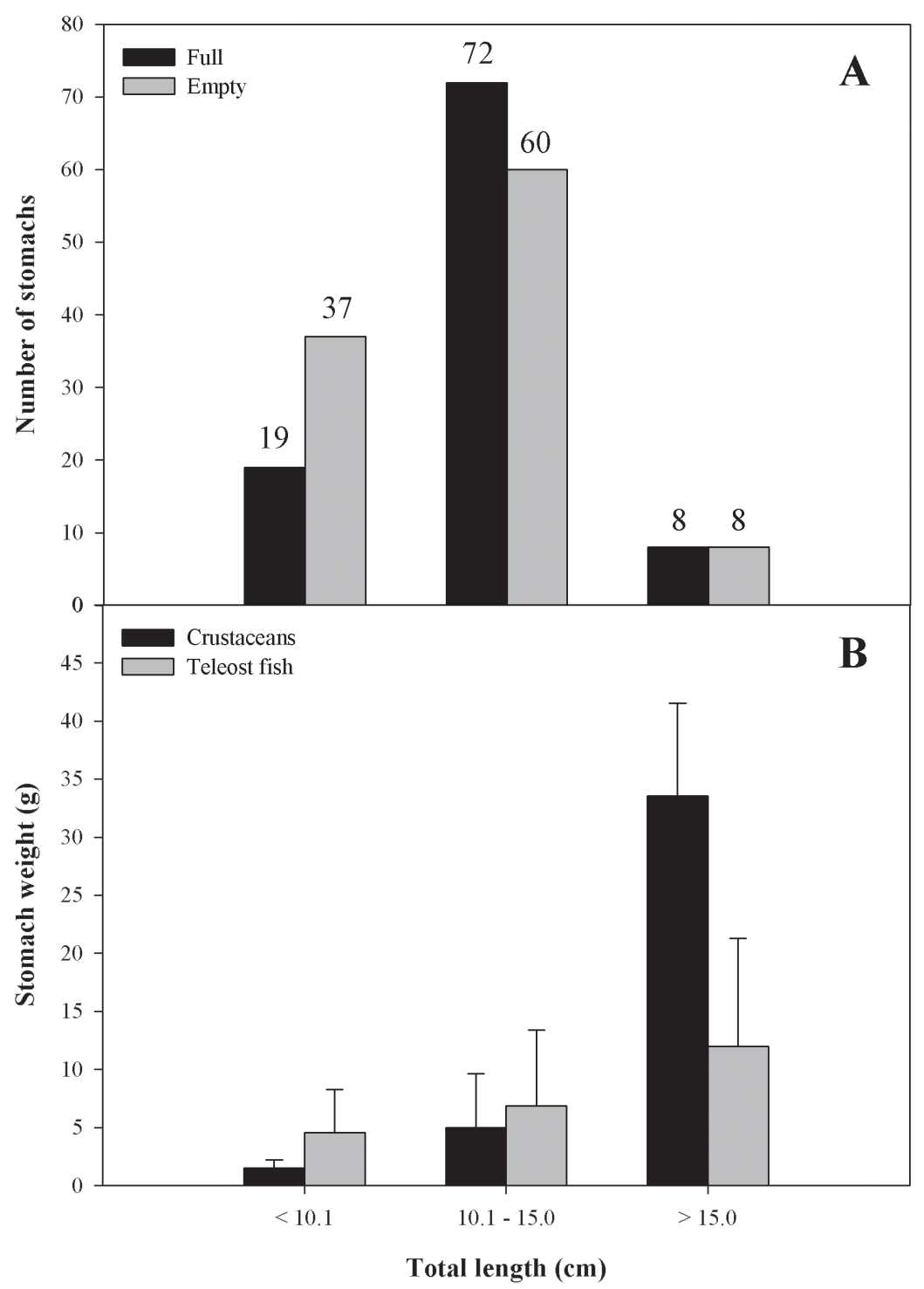

Fig. 3. A - Number of full and empty stomachs by size categories for the threadfin anglerfish (Lophiodes spilurus). $\mathrm{B}$ - Average stomach weight $(\mathrm{g} \pm$ standard error) by size categories from specimens collected in the central Pacific of Costa Rica.

small and large-sized individuals $\left(\mathrm{O}_{\mathrm{ac}}=0.18\right.$, $\mathrm{p}>0.05)$ or intermedium and large-sized individuals $\left(\mathrm{O}_{\mathrm{bc}}=0.18, \mathrm{p}>0.05\right)$.

A strong significant relationship was observed in the length-weight of L. spilurus $\left(\mathrm{F}_{1}\right.$, $\left.{ }_{93}=293, \mathrm{p}<0.001\right)$, where larger individuals typically had heavier stomachs $\left(\mathrm{F}_{1,93}=39.50, \mathrm{p}\right.$ $<0.001$ ) (Fig. 4). The average stomach weight of all individuals was $7.26 \pm 6.73 \mathrm{~g}$ (range: 0.10 $40.40 \mathrm{~g}$ ). In addition, we also found that stomachs from L. spilurus containing crustaceans were significantly heavier than those containing teleost fish $\left(\mathrm{F}_{1,107}=8.01, \mathrm{p}=0.005\right)$. Moreover, we found that large-sized $L$. spilurus preyed on significantly larger prey items than intermediate and small-sized individuals, suggesting an 
TABLE 2

Prey items observed (N), number of stomachs with an item (n), frequency of occurrence (Fo), and percentage of occurrence $(\% O)$ in three different size groups of Lophiodes spilurus from the central Pacific of Costa Rica

\begin{tabular}{|c|c|c|c|c|c|c|c|c|c|c|c|c|}
\hline \multirow{2}{*}{ Prey category } & \multicolumn{4}{|c|}{$0-10 \mathrm{~cm} \mathrm{TL}$} & \multicolumn{4}{|c|}{$10.1-15 \mathrm{~cm} \mathrm{TL}$} & \multicolumn{4}{|c|}{$15.1-20 \mathrm{~cm} \mathrm{TL}$} \\
\hline & $\mathrm{N}$ & $\mathrm{n}$ & Fo & $\% \mathrm{O}$ & $\mathrm{N}$ & $\mathrm{n}$ & Fo & $\% \mathrm{O}$ & $\mathrm{N}$ & $\mathrm{n}$ & Fo & $\% \mathrm{O}$ \\
\hline Crustacea & 4 & 4 & 7.55 & 20 & 25 & 22 & 18.80 & 29.41 & 5 & 4 & 33.33 & 55.56 \\
\hline Plesionika trispinus & 3 & 3 & 5.66 & 15 & 17 & 15 & 12.78 & 20 & & & & \\
\hline Heterocarpus vicarius & & & & & 3 & 2 & 2.26 & 3.53 & & & & \\
\hline Solenocera agassizii & & & & & 1 & 1 & 0.75 & 1.18 & & & & \\
\hline Squilla biformis & & & & & & & & & 2 & 1 & 13.33 & 22.22 \\
\hline Squilla panamensis & & & & & & & & & 3 & 3 & 20 & 33.33 \\
\hline Pleuroncodes sp. & & & & & 1 & 1 & 0.75 & 1.18 & & & & \\
\hline Digested shrimps & 1 & 1 & 1.89 & 5 & 3 & 3 & 2.26 & 3.53 & & & & \\
\hline Teleostei & 16 & 15 & 30.19 & 80 & 60 & 54 & 45.11 & 70.59 & 4 & 4 & 26.67 & 44.44 \\
\hline Bollmannia stigmatura & 3 & 3 & 5.66 & 15 & 1 & 1 & 0.75 & 1.18 & & & & \\
\hline Bollmannia sp. & 1 & 1 & 1.89 & 5 & 4 & 4 & 3.01 & 4.71 & & & & \\
\hline Brotula clarkei & & & & & 1 & 1 & 0.75 & 1.18 & & & & \\
\hline Neobythites stelliferoides & & & & & 4 & 4 & 3.01 & 4.71 & & & & \\
\hline Lepophidium microlepis & & & & & 3 & 2 & 2.26 & 3.53 & & & & \\
\hline Ophidiidae & 3 & 3 & 5.66 & 15 & 1 & 1 & 0.75 & 1.18 & & & & \\
\hline Physiculus nematopus & 1 & 1 & 1.89 & 5 & & & & & & & & \\
\hline Physiculus rastrelliger & 2 & 2 & 3.77 & 10 & 9 & 9 & 6.77 & 10.59 & 1 & 1 & 6.67 & 11.11 \\
\hline Symphorus fasciliolaris & 1 & 1 & 1.89 & 5 & 1 & 1 & 0.75 & 1.18 & & & & \\
\hline Symphorus sp. & & & & & 1 & 1 & 0.75 & 1.18 & & & & \\
\hline Cynoponticus coniceps & & & & & 1 & 1 & 0.75 & 1.18 & & & & \\
\hline Hoplunnis pacifica & 1 & 1 & 1.89 & 5 & 2 & 2 & 1.50 & 2.35 & 1 & 1 & 6.67 & 11.11 \\
\hline Pontinus sierra & 1 & 1 & 1.89 & 5 & 2 & 2 & 1.50 & 2.35 & & & & \\
\hline Prionotus stephanophrys & & & & & 1 & 1 & 0.75 & 1.18 & & & & \\
\hline Unidentified teleost fish & 2 & 1 & 3.77 & 10 & 22 & 22 & 16.54 & 25.88 & & & & \\
\hline Digested teleost fish & 1 & 1 & 1.89 & 5 & 7 & 7 & 5.26 & 8.24 & 2 & 2 & 13.33 & 22.22 \\
\hline TOTAL & 20 & 18 & 37.74 & 100 & 85 & 71 & 63.91 & 100 & 9 & 7 & 60 & 100 \\
\hline
\end{tabular}

ontogenetic diet-shift $\left(\mathrm{F}_{2,107}=13.19, \mathrm{p}<0.001\right.$; Fig. 3).

\section{DISCUSSION}

The threadfin angler L. spilurus is one of the most common species associated with the deepwater shrimp fishery along the Pacific coast of Costa Rica (Wehrtmann, unpubl. data).
Along the Eastern Tropical Pacific coast $L$. spilurus has a maximum length of $30.0 \mathrm{~cm}$ TL (Caruso 1995). However, Bussing and López (1993, 2005) already indicated that individuals of this species collected along the Pacific coast of lower Central America do not reach this maximum size. Thus, our size data of $L$. spilurus are in accordance with previous data published for the study area. 


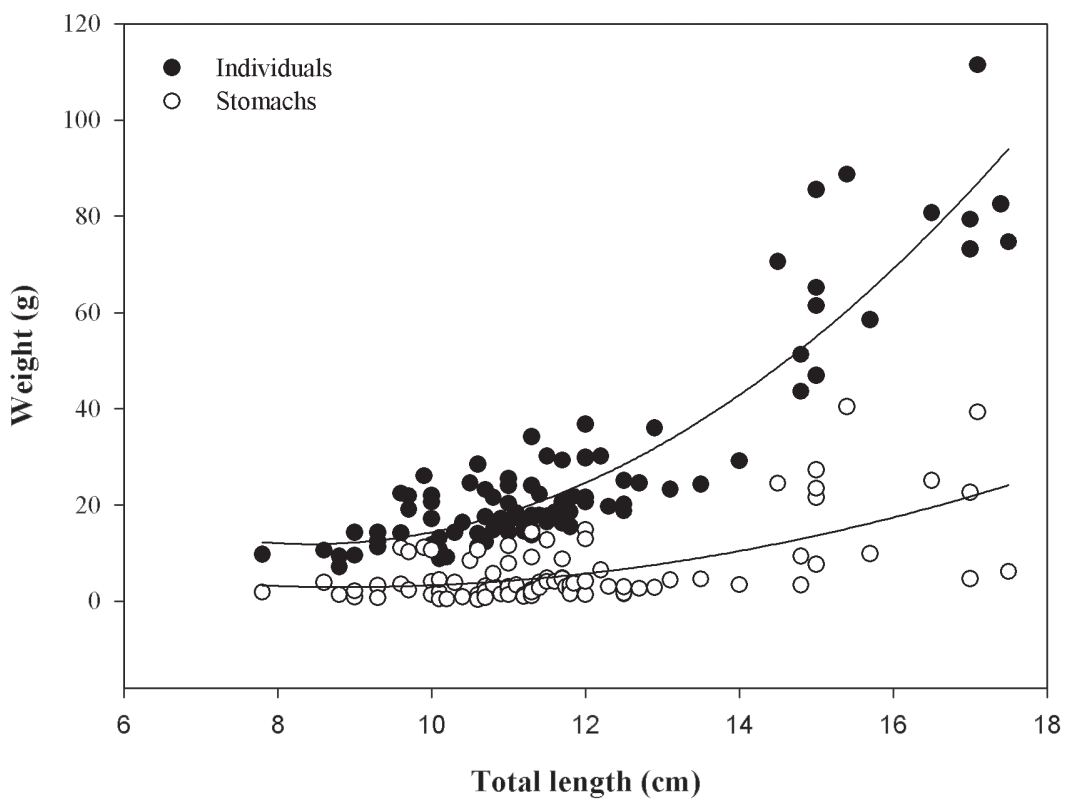

Fig. 4. Total length $(\mathrm{cm})$ and weight $(\mathrm{g})$ relationship for the threadfin anglerfish (Lophiodes spilurus) from the central Pacific of Costa Rica. Individuals: $y=0.9969 x^{2}-16.803 x+82742, R^{2}=0.85$; Stomachs: $y=0.2841 x^{2}-5.0387 x+25.352, R^{2}$ $=0.38)$.

Our knowledge concerning the stomach contents of fishes in Costa Rica is principally based on studies carried on commercially important shallow water fishes from the Gulf of Nicoya, Pacific of Costa Rica (Rojas 1997a, 1997b, 2006). This is the first systematic study of stomach contents from the deepwater threadfin anglerfish L. spilurus along the Pacific coast of Central America. Our samples were obtained during day-time by commercial shrimp boats, and their routine did not allow designing a sampling strategy to elucidate possible daily feeding patterns in L. spilurus, which probably explains the relatively high percentage of empty stomachs.

In most stomachs with at least one prey item, we encountered remains of fish bones and digested material, which limited the identification process. However, our results clearly demonstrate that L. spilurus is feeding exclusively on two prey groups: benthic teleost fish and crustaceans. Since L. spilurus posses a relatively low mobility and special adaptations to
TABLE 3

Heterogeneity $\left(H^{\prime}\right)$ and evenness $(J)$ of food items found in stomach contents from three different size groups of threadfin anglerfish (Lophiodes spilurus) from the central Pacific of Costa Rica. The Shannon-Wiener diversity index was used as a measure of heterogeneity

$\begin{array}{lcccc}\begin{array}{l}\text { Total length } \\ (\mathrm{cm})\end{array} & \mathrm{n} & \mathrm{H}, & \mathrm{H}_{\max } & \mathrm{J} \\ <10.1 & 12 & 3.41 & 3.58 & 0.95 \\ 10.1-15.0 & 20 & 3.57 & 4.72 & 0.76 \\ >15.0 & 5 & 2.2 & 2.32 & 0.95\end{array}$

attract their prey (Caruso 1981, 1995, Caruso et al. 2007), it is not surprising that most individuals analyzed contained benthic prey species known to occur on sandy or muddy soft bottom substrates of the continental shelf (Bussing and López 1993, 2005, Caruso 1995, Wehrtmann and Echeverría-Sáenz 2007). Our results are in accordance to Preciado et al. (2006), who found that the diet of a similar species, the 
black anglerfish Lophius budegassa from the North Atlantic coast of Spain, included mainly small benthic teleost fish such as the blue whiting Micromesistius poutassou, the greater forkbeard Phycis blennoides and the European hake Merluccius merluccius.

Crustacean prey items found in threadfin anglerfish stomachs reflect the diversity of the deepwater shrimp bycatch composition in Pacific Costa Rica (Wehrtmann and EcheverríaSáenz 2007). Diet composition of L. spilurus revealed an important portion of pandalid shrimps, stomatopods and squat lobsters in individuals smaller than $15.0 \mathrm{~cm}$ TL. According to Salgado-Barragán and Hendrickx (1991), crustaceans represent a high portion of the deepwater shrimp fishery bycatch in Pacific Mexico, and are predominant in deepwater shrimp catches along the Pacific coast of Costa Rica (Wehrtmann and Echeverría-Sáenz 2007). Salgado-Barragán and Hendrickx (1991) found that Squilla panamensis and Squilla biformis were the two most abundant stomatopods species associated with shrimp fisheries carried out in the Mexican littoral and continental shelf region. Moreover, S. biformis is a frequent and sometimes dominant bycatch species of deepwater shrimp fisheries in the Pacific coast of Costa Rica (Wehrtmann and Echeverría-Sáenz 2007). Despite their relative abundance in shrimp catches, stomatopods and squat lobsters (Galatheidae) were not a common food item for L. spilurus and were found exclusively in specimens larger than $10.1 \mathrm{~cm}$ TL, which suggest that prey selection might be size dependent in threadfin anglerfish (Armstrong et al. 1996, Laurenson and Priede 2005). This finding is in accordance with similar results regarding the stomach contents of deepwater fishes in other regions (Sabatés and Saiz 2000, Preciado et al. 2006).

Intermediate size individuals of $L$. spilurus preyed on a greater diversity of food items than smaller $(<10.1 \mathrm{~cm} \mathrm{TL})$ and larger specimens ( $>15.0 \mathrm{~cm} \mathrm{TL}$ ). According to Rojas-Herrara et al. (2004), prey availability rather than prey selectivity affects the feeding behavior in snappers (Lutjanus spp.) from Pacific Mexico.
Considering that in our study area prey availability was similar for all size classes, the results of the present study indicate a clear tendency of prey selectivity in small and large individuals. Medium size fishes seem to represent a transitional phase, preying on species preferred by small and large individuals. Such selectivity is evident, because stomatopods were exclusively found in stomachs of large individuals $(>15.0 \mathrm{~cm} \mathrm{TL})$, and represented $56 \%$ of the occurrence of prey items (Table 2 ). Our findings thus support the hypothesis that prey selectivity of different ontogenetic stages of L. spilurus favors a more efficient utilization of available food resources (Preciado et al. 2006).

An interesting finding was observed in the diet patterns of L. spilurus from the Central Pacific of Costa Rica. Although several studies have identified an ontogenetic diet shift to piscivory in many predatory fish (Lowe et al. 1996, Mittelbach and Persson 1998, Peterson et al. 2006), in this study we found the opposite pattern. While small and intermediate-sized L. spilurus fed mainly on teleost fish and a wide variety of smaller invertebrates, larger invertebrates such as stomatopods, were only found in large-sized L. spilurus. Peterson et al. (2006) observed an ontogenetic diet shift to piscivory in 1-year-old rock bass, however they also noticed that the diet of another fish, the bluegills, continued to be dominated by invertebrates in older individuals. Invertebrate diets typically have a higher proportion of indigestible material (chitin) compared with piscivory (Stewart et al. 1983), and consumptions rate must increase accordingly to meet daily energetic requirements (Pazzia et al. 2002). Consequently, foraging costs are much higher for predators feeding on small invertebrates, resulting in lower growth rate efficiencie and growth rates (Pazzia et al. 2002). Although in this study, large-sized L. spilurus appear to feed mainly on larger invertebrates we only analyzed a relatively small sample size of full stomachs, therefore any conclusions should be made with caution. However, due to the high abundance of stomatopods and other 
large invertebrates in the area (Wehrtmann and Echeverría-Sáenz 2007), an ontogenetic diet shift of L. spilurus to an invertebrate diet could result in more energetic prey items consumed by large-sized individuals.

Stomach contents of deepwater fishes along the tropical Eastern Pacific have been poorly studied. The present study revealed that the diet composition of L. spilurus includes a high diversity of food items, but that this diversity of prey was restricted to just two major taxa, teleost fish and crustaceans. Although we found evidence of an ontogenetic diet shift between small-intermediate and large-size $L$. spilurus, due to the low number of individuals with full stomachs and unequal sample sizes among size-classes, any conclusion should be made with caution. A more detailed study of the diet, as well as further research into other aspects of the ecology and feeding behavior can provide more information of this benthic predator and its role in the trophic dynamic of deepwater ecosystems.

\section{ACKNOWLEDGMENTS}

We thank The Rainbow Jewels S.A. Company (Puntarenas, Costa Rica) for allowing us to collect samples on board of their commercial shrimp boats. Special thanks go to the captain of the boat "Onuva", Rigoberto Villalobos Cruz, and the general manager of The Rainbow Jewels S.A., Ronny Gründler, for their constant and ongoing support. The study was part of a larger project concerning the development of standards for sustainable deepwater shrimp fisheries in Pacific Costa Rica. Funding was generously provided by the German Federal Ministry of Economic Cooperation and Development (BMZ), and the company Ristic AG (Oberferrieden, Germany). We are also grateful to the Vicerrectoría de Investigación of the Universidad de Costa Rica for their support (project V.I. N ${ }^{0} 111-A 4-508$ ). Finally, we express our gratitude to Alicia Rodríguez Pérez-Porro and Quiterie Duron for their help with sample processing, and to
Vanessa Nielsen and Fresia Villalobos for the collection of the samples.

\section{RESUMEN}

Nuestro conocimiento de los ecosistemas marinos de profundidad a lo largo de la costa centroamericana es muy limitado. En el presente estudio se analizó la composición alimenticia de 200 especimenes adultos de Lophiodes spilurus que medían entre 7.8 y $17.8 \mathrm{~cm}$ longitud total (LT). Las muestras fueron obtenidas de arrastres camaroneros (profundidad: 105-238 m) a lo largo del Pacífico Central de Costa Rica. Calculamos el porcentaje del número ( $\%$ $\mathrm{N})$, peso $(\% \mathrm{~W})$ y presencia $(\% \mathrm{O})$ de cada ítem alimenticio encontrado en los estómagos. Basados en esta información, calculamos el Índice de Importancia Relativa (IR). Además, estimamos el traslape en la dieta de tres diferentes clases de tamaño $(<10.1,10.1-15.0 \mathrm{y}>15.0 \mathrm{~cm}$ LT). Los resultados revelaron, exclusivamente, dos grupos de presas bentónicas: crustáceos $(30 \%)$ y peces teleósteos $(70 \%)$. Las presas más frecuentes fueron el camarón pandalido Plesionika trispinus $(\% \mathrm{O}=17)$ y la mora Physiculus rastrelliger $(\%$ $0=12$ ). La mayor diversidad y frecuencia de abundancia de ítems alimenticios se observó en individuos intermedios $(10.1-15.0 \mathrm{~cm}$ LT). Individuos pequeños $(<10.1 \mathrm{~cm}$ TL) se alimentaron principalmente de peces teleósteos, mientras que individuos de mayor tamaño $(>15.0 \mathrm{~cm} \mathrm{TL})$ consumieron organismos de mayor tamaño y peso como estomatópodos y peces teleósteos. Se encontró un claro traslape en la composición alimenticia de individuos de tamaño pequeño e intermedio de L. spilurus $(\mathrm{p}<0.05)$. Sin embargo, estas diferencias no se detectaron en individuos de tamaño pequeño y grande, ni en individuos intermedios $y$ grandes $(p>0.05)$. Nuestros resultados sugieren que en el Pacífico de Costa Rica L. spilurus se alimenta exclusivamente de crustáceos (Decapoda and Stomatopoda) y peces teleósteos bentónicos. Los especimenes medianos parecen alimentarse de forma oportunista.

Palabras clave: composición alimenticia, profundidad, Lophiodes spilurus, Pacífico de Costa Rica, presas, traslape alimenticio.

\section{REFERENCES}

Allen, G.R. \& D.R. Robertson. 1994. Fishes of the Tropical Eastern Pacific. University of Hawaii. Honolulu, Hawaii, USA. 332p.

Armstrong, M.P., J.A. Musick \& J.A. Colvocoresses. 1996. Food and ontogenetic shifts in feeding of the goosefish, Lophius americanus. J. North. Atlantic. Fish. Science. 18: 99-103.

Arendt, M.D. \& J.E. Olney. 2001. Stomach content analysis for cobia, Rachycentron canadum, from lower Chesapeake Bay. Fish. Bull. 99: 665-670. 
Bussing, W.A. \& M.I. López. 1993. Demersal and pelagic inshore fishes of the Pacific coast of lower Central America. Univ. Costa Rica. San Pedro, San José, Costa Rica. 164 p.

Bussing, W.A. \& M.I. López. 2005. Fishes of Cocos Island and reef fishes of the Pacific coast of lower Central America. Rev. Biol. Trop. 53: 7-192.

Caruso, J.H. 1981. The systematics and distribution of the lophiid anglerfishes. I: A revision of the genus Lophiodes with the description of two new species. Copeia 1981: 522-549.

Caruso, J.H. 1983. The systematics and distribution of the lophiid anglerfishes. II: Revisions of the genera Lophiomus and Lophius. Copeia 1983:11-30.

Caruso, J.H. 1995. Family Lophiidae. In W. Fischer; Krupp, F.; Schneider, W.; Sommer, C.; Carpenter, K. E.; Niem, H. V. 1227-1230 p. Guía FAO para la identificación de especies para los fines de la pesca. Pacifico centro-oriental. Vol. III. Vertebrados Parte 2. FAO of the United Nations, Rome, Rome, Italy.

Caruso, J.H., S.W. Ross, K.J. Sulak \& G.R. Sedberry. 2007. Deep-water chaunacid and lophiid anglerfishes (Pisces: Lophiiformes) off the south-eastern United States. J. Fish. Biol. 70: 1015-1026.

Cortés, E. 1997. A critical review of methods of studying fish feeding based on analysis of stomach contents: applications to elasmobranch fishes. Can. J. Fish. Aquat. Sci. 54: 726-738.

Cortés, E. 1999. Standardized diet compositions and trophic levels of sharks. J. Mar. Sci. 56: 707-717.

Dávalos, E. \& E. Gónzalez. 2003. Stomach content of one pelagic ray Dasyatis violacea (Bonaparte 1832) (Rajiformes: Dasyatidae) from the Gulf of California, Mexico. Oceánides. 18: 43-44.

Dean, H.K. 2001a. Some Nereididae (Annelida: Polychaeta) from the Pacific coast of Costa Rica. Rev. Biol. Trop. 49: 37-68.

Dean, H.K. 2001b. Marine biodiversity of Costa Rica: The Phyla Sipuncula and Echiura. Rev. Biol. Trop. 49: 85-90.

Glenn, C.L. \& E.J. Ward. 1968. Wet weight as a method of measuring stomach contents of Walleyes, Stizostedion vitreum. J. Fish. Res. B Can. 25: 1505-1507.
Hyslop, E.J. 1980. Stomach content analysis: a review of methods and their application. J. Fish. Biol. 17: 411-429.

Ibáñez, C.H., C. González \& L. Cubillos. 2004. Dieta del pez espada Xiphias gladius Linnaeus, 1758, en aguas oceánicas de Chile central en invierno de 2003. Invest. Mar., Valparaíso 32: 113-120.

Ikusemiju, K. \& C.I. Olaniyan. 1977. The food and feeding habitats of the catfishes, Chrysichthys walkeri (Gunther), Chrysichthys filamentosus (Boulenger) and Chrysichthys nigrodigitatus (Lacépéde) in the Lekki Lagoon, Nigeria. J. Fish. Biol. 10: 105-112.

Joyce, W.N., S.E. Campana, L.J. Natanson, N.E. Kohler, H.L Pratt \& C.F. Jensen. 2002. Analysis of stomach contents of the porbeagle shark (Lamna nasus Bonnaterre) in the northwest Atlantic. J. Mar. Sci. 59: 1263-1269.

Krebs, C.J. 1999. Ecological Methodology. $2^{\text {nd }}$ ed. Benjamin/Cummings. San Francisco, California, USA. 620 p.

Laurenson, C.H. \& I.G. Priede. 2005. The diet and trophic ecology of anglerfish Lophius piscatorius at the Shetland Islands, UK. J. Mar. Biol. Assoc. 85: 419-424.

Lowe C.G, B.M. Wetherbee, G.L. Crow \& A.L. Tester. 1996. Ontogenetic dietary shifts and feeding behavior of the tiger shark, Galeocerdo cuvier, in Hawaiian waters. Environ. Biol. Fish. 47: 203-211.

Mittelbach, G.G. \& L. Persson. 1998. The ontogeny of piscivory and its ecological consequences. Can. J. Fish. Aquat. Sci. 55: 1454-1465.

Molina, H. 1996. Ichthyoplankton assemblages in the Gulf of Nicoya and Golfo Dulce embayments, Pacific coast of Costa Rica. Rev. Biol. Trop. 44: 173-182.

Nelson, J.S. 1994. Fishes of the world. $3^{\text {th }}$ ed. John Wiley \& Sons. New York, New York, USA. 600 p.

Paterson, G., K. G. Drouillard \& D. Haffner. 2006. An evaluation of stable nitrogen isotopes and polychlorinated biphenyls as bioenergetic tracers in aquatic systems. Can. J. Fish. Aquat. Sci. 63: 628-641.

Pazzia, I., M. Trudel, M. Ridgway \& J.B. Rasmussen. 2002. Influence of food web structure on the growth and bioenergetics of lake trout (Salvelinus namaycush). Can. J. Fish. Aquat. Sci. 59: 1593-1605. 
Pianka, E.R. 1973. The structure of lizards communities. Ann. Rev. Ecol. Syst. 4: 53-74.

Pielou, E.C. 1975. Ecological Diversity. John Wiley \& Sons. New York, New York, USA. 176 p.

Preciado, I., F. Velasco, I. Olaso \& J. Landa. 2006. Feeding ecology of black anglerfish Lophius budegassa: seasonal, bathymetric and ontogenetic shifts. J. Mar. Biol. Assoc. 86: 877-884.

Rojas, J.R. 1997a. Hábitos alimentarios del pargo mancha Lutjanus guttatus (Pisces: Lutjanidae) en el Golfo de Nicoya, Costa Rica. Rev. Biol. Trop. 45: 471-476.

Rojas, J.R. 1997b. Dieta del pargo colorado Lutjanus colorado (Pisces: Lutjanidae) en el Golfo de Nicoya, Costa Rica. Rev. Biol. Trop. 45: 1173-1183.

Rojas, J.R. 2006. Reproducción y alimentación del tiburón enano Mustelus dorsalis (Pisces: Triakidae) en el Golfo de Nicoya, Costa Rica: elementos para un manejo sostenible. Rev. Biol. Trop. 54: 861-871.

Rojas-Herrera, A. A., M. Mascaro \& X. Chiappa-Carrara. 2004. Hábitos alimenticios de los peces Lutjanus peru y Lutjanus guttatus (Pisces: Lutjanidae) en Guerrero, México. Rev. Biol. Trop. 52: 959-971.

Sabatés, A. \& E. Saiz. 2000. Intra- and interspecific variability in prey size and niche breadth of myctophiform fish larvae. Mar. Ecol. Prog. Ser. 201: 261-271

Salgado-Barragán. J. \& M.E. Hendrickx. 1991. Los estomatópodos (Crustacea: Hoplocarida) del Pacífico Mexicano. Inst. Cienc. Mar y Limnol. UNAM. MExico DF, Mexico. Publ. Esp. 10: 1-200.

Steward, D.J., D. Weininger, D. V. Rottiers \& T. A. Edsall. 1983. An energetic model for lake trout, Salvelinus namaycush: application to the Lake Michigan population. Can. J. Fish. Aquat. Sci. 40: 681-698.

Wehrtmann, I.S. \& J. Cortés. (in press). Marine Biodiversity of Costa Rica, Central America. Series Monographiae Biologicae, Vol. 86, Springer Verlag, Berlin, Germany.

Wehrtmann, I.S. \& S. Echerverría-Sáenz. 2007. Crustacean fauna (Stomatopoda, Decapoda) associated with the deepwater fishery of Heterocarpus vicarius (Decapoda, Pandalidae) along the Pacific coast of Costa Rica. Rev. Biol. Trop. 55: 121-130. 